Адзерихо И.Э. ${ }^{,}$, Яцевич О.Н. ${ }^{2}$, Владимирская Т.э. ${ }^{2}$, Михневич Д.Л. ${ }^{2}$

\title{
Морфологические изменения в динамике легочной артериальной гипертензии, индуцированной монокроталином в эксперименте in vivo
}

\author{
'ГУО «Белорусская медицинская академия последипломного образования», \\ 220013, Минск, Республика Беларусь, ул. П. Бровки, д. 3, корп. 3; \\ 2ГУО НИЛ «Белорусская медицинская академия последипломного образования», Минздрава Республики Беларусь, \\ Минский район, Республика Беларусь, агрогородок Лесной, д. 31
}

\begin{abstract}
Цель исследования - изучение временной динамики морфологических изменений легочной ткани и миокарда правого желудочка у крыс на модели легочной артериальной гипертензии, индуцированной монокроталином. Методика. Исследование выполнено на 80 беспородных белых крысах. Для моделирования легочной артериальной гипертензии крысам вводили подкожно монокроталин в дозе 60 мг/кг. Материал для морфологического исследования (образцы тканей легких и миокарда) брали через 2, 4, 6 и 8 нед после введения монокроталина. Контролем служили образцы соответствующих тканей интактных животных. Результаты. В течение первых 4 нед эксперимента выявлялись начальные признаки структурного ремоделирования легочной ткани и миокарда. Это проявлялось гипертрофией медиального слоя легочных артерий с сохранением сосудистого просвета на фоне незначительных периваскулярных лимфоцитарных инфильтратов, появлением признаков активации апоптотической гибели эндотелиоцитов, а также сегментарными повреждениями кардиомиоцитов с развитием гипертрофии правого желудочка. К концу эксперимента наблюдались необратимые прогрессирующие во времени патологические изменения в исследуемых тканях. В легочной ткани появлялись участки плексиформной артериопатии, а также полное закрытие просвета легочных сосудов с выраженной околососудистой реакцией. Облитерация просвета сосудов обусловлена как гипертрофией медии, так и выраженным фиброзом интимы. В правом желудочке были обнаружены признаки мелкоочагового некроза кардиомиоцитов с участками заместительного фиброза и развитием дилатации правых отделов сердца. Заключение. В эксперименте in vivo установлены временные интервалы обратимости морфологических изменений легочной ткани и миокарда правых отделов сердца, характерные для легочной артериальной гипертензии.
\end{abstract}

Ключевые слова: легочная артериальная гипертензия; монокроталиновая модель; структурное ремоделирование легочной ткани и миокарда правого желудочка; апоптоз.

Для цитирования: Адзерихо И.Э., Яцевич О.Н., Владимирская Т.Э., Михневич Д.Л. Морфологические изменения в динамике легочной артериальной гипертензии, индуцированной монокроталином в эксперименте in vivo. Патологическая физиология и экспериментальная терапия. 2020; 64(1): 60-66.

DOI: 10.25557/0031-2991.2020.01.60-66

Для корреспонденции: Яцевич Ольга Николаевна, e-mail: o-n-y@yandex.ru

Финансирование. Работа выполнена при финансовой поддержке фонда БРФФИ, грант № М17-113.

Конфликт интересов. Авторы заявляют об отсутствии конфликта интересов.

Поступила 09.07.2019

Принята к печати 16.01.2020

Опубликована 25.02.2020

Adzericho I.E. ${ }^{1}$, Jacevich O.N. ${ }^{2}$, Vladimirskaja T.E. ${ }^{2}$, Mihnevich D.L. ${ }^{2}$

Morphological features in dynamics of monocrotaline-induced pulmonary arterial hypertension in vivo

'Belarusian Medical Academy of Postgraduate Education,

Minsk 220013, Republic of Belarus, str. P. Brovki 3, korp. 3;

${ }^{2}$ Scientific Research Laboratory, Division of General Pathology, Belarusian Medical Academy of Postgraduate Education,

Lesnoy Village 1, Minsk Region 223040, Republic of Belarus

Objective. To investigate the dynamics of pathomorphological changes in lung and right ventricular tissues in rats following injections of $60 \mathrm{mg} / \mathrm{kg}$ monocrotaline for 8 weeks. Methods. The study was performed on white mongrel male rats treated with monocrotaline $60 \mathrm{mg} / \mathrm{kg}$, s.c. Samples of lung and heart tissues were collected for morphological studies every two weeks following the monocrotaline treatment. Results. In the first four weeks of the experiment, initial signs of structural remodeling were observed 
DOI: 10.25557/0031-2991.2020.01.60-66

in the lungs and myocardium. These signs were evident as medial hypertrophy of pulmonary arteries with preserved lumen and minor perivascular infiltrates; increased apoptosis of endothelial cells; and segmental injury of cardiomyocytes with right ventricular hypertrophy. Irreversible, progressive pathology was observed in studied tissues by the end of experiment, which included occlusion of the vascular lumen in pulmonary arteries due to intimal fibrosis and medial hypertrophy in the lung tissue affected by perivascular inflammation. Plexiform arteriopathy was established in some samples at 8 weeks. Right ventricular cardiomyocytes showed aseptic necrosis with transformation into reactive fibrosis and right heart dilatation. Conclusion. This in vivo study established the time windows for reversibility of morphological alterations in lung and myocardial tissues characteristic of pulmonary arterial hypertension.

Keywords: pulmonary arterial hypertension, monocrotaline model, structural remodeling of lung and myocardial tissues, apoptosis.

For citation: Adzericho I.E., Jacevich O.N., Vladimirskaja T.E., Mihnevich D.L. Morphological features in dynamics of monocrotaline inducted pulmonary arterial hypertension in vivo. Patologicheskaya Fiziologiya i Eksperimental naya terapiya. (Pathological Physiology and Experimental Therapy, Russian Journal). 2020; 64(1): 60-66. (in Russian).

DOI: 10.25557/0031-2991.2020.01.60-66

For correspondence: Olga N. Jacevich, Junior researcher, Department of General pathology
Belarus, e-mail: o-n-y@yandex.ru
Information about authors:
Adzerikho I. E., https://orcid.org/0000-0001-6572-8842
Jacevich O. N., http://orcid.org./0000-0001-8633-2628
Vladimirskaja T.J., https://orcid.org/0000-0002-0777-192X
Mihnevich D.L., https://orcid.org/0000-0001-6808-566X
Conflict of interest. The authors declare no conflict of interest.
Acknowledgments. This work was supported by the BRFFR Foundation, Grant № M17-113.
Received 09.07.2019
Accepted 19.01.2020
Published 25.02 .2020

\section{Введение}

В последние годы монокроталиновая модель является основной для изучения легочной артериальной гипертензии (ЛАГ). Развивающийся при действии токсина комплекс морфологических изменений (легочный фиброз, гипертрофия медиального слоя легочных сосудов, гипертрофия и дилатация правого желудочка, адвентициальные воспалительные изменения, печеночная венноокклюзионная болезнь) в научной литературе известен как монокроталиновый синдром [1]. Вместе с тем, до настоящего времени нет четких стандартов доз по введению токсина, поскольку обусловленные им изменения наблюдаются в достаточно широком диапазоне доз. Кроме того, также отсутствуют данные четкой детализации патогистологических процессов в легочной ткани и миокарде крыс в динамике развития монокроталинового синдрома при моделировании ЛАГ.

Цель исследования - изучение динамики развития патоморфологических изменений легочной ткани и миокарда правого желудочка крыс на монокроталиновой модели ЛАГ.

\section{Методика}

Эксперименты выполнены на базе отдела общей патологии «Научно-исследовательской лаборатории
Белорусской медицинской академии последипломного образования» и одобрены этическим комитетом академии. При проведении исследований руководствовались соблюдением требований Европейской конвенции (Страсбург, 1986) по содержанию, кормлению и уходу за подопытными животными, а также выводу их из эксперимента с последующей утилизацией с учетом требований и рекомендаций, нормативных, научнометодических и справочных материалов [2].

В работе использовано 80 беспородных белых крыссамцов, массой 250-300 г, в возрасте 8 нед на начало эксперимента. Животных содержали в стандартных условиях вивария при свободном доступе к воде и пище. Для воспроизведения ЛАГ использовали 8-недельную монокроталиновую модель [3]. Раствор монокроталина получали путем растворения кристаллов монокроталина (Sigma, Германия) в подогретом до 30 은 физиологическом растворе. Крысы были разделены на 2 группы по 40 животных в каждой. Экспериментальной группе вводили 1,0 мл раствора монокроталина (60 мг/кг) утром натощак подкожно в область холки, группе контроля эквивалентное количество физиологического раствора. Животные, которым вводили раствор монокроталина, были дополнительно разделены в соответствии с про- 
должительностью наблюдения: 2, 4, 6 и 8 нед (соответственно подгруппы M2, M4, М6 и М8). Контрольные группы М0 составили крысы, которым вводили утром натощак в область холки 1,0 мл физиологического раствора. При завершении эксперимента всех животных выводили из опыта, используя смесь 1,0 мл 0,005\% раствора фентанила и 2,0 мл 0,25\% раствора дроперидола (в соответствии со стандартами GLP).

Для гистологического исследования забирали легкие и сердце в соответствии с протоколом. Из образцов тканей готовили парафиновые срезы, которые окрашивали гематоксилином и эозином, по Массону, гематоксилином - основным фуксином с пикриновой кислотой (ГОФП). Дальнейшее изучение микропрепаратов и изготовление микрофотографий проводили с помощью микроскопов Leica DMLS и Axio Imager (Германия). Морфометрический анализ и статистическую обработку результатов проводили при помощи программно-аппаратного комплекса «Leica-Qwin». Измерение толщины стенки легочных артерий проводили при увеличении $\times 400$. Для выявления апоптоза клеток сосудов использовали метод TUNEL, основанный на мечении концевых отделов апоптозоспецифичных моно- и олигонуклеосомных фрагментов ядерной ДНК. Индекс апоптоза (АИ) рассчитывали как отношение числа TUNEL-позитивных клеток (при ув. $\times 1000$ в 10 полях зрения) в процентах к общему количеству клеток. Статистическую обработку проводили с использованием пакета прикладных программ «Міcrosoft Excel 2010» и «Statistica» (версия 10,0, StatSoft, Inc., США). Критериями оценки выступали Ме [25\%; 75\%], где Ме - медиана, [25\%; 75\%] - 25-я и 75-я процентили; U-критерий Манна-Уитни (для независимых выборок); уровень значимости $-p<0,05$.

\section{Результаты}

1. Общая характеристика животных. Осмотр животных каждые 2 нед выявил прогрессирующее ухудшение состояния крыс после инъекции монокроталина. Так, через 2 нед (в гр. М2) наблюдалось снижение двигательной активности крыс, а через 4 нед (гр М4) отмечена тенденция к уменьшению прироста массы тела по сравнению с группой контроля (Me=31,13 г vs $19,7$ г, $p>0,05)$. Через 6 нед (гр. М6) появились признаки правожелудочковой недостаточности: у $30 \%$ крыс развивался асцит, отсутствовал прирост массы тела (Me $=44,0$ г vs 25,38 г, $p>0,05)$. В группе М6 $20 \%$ животных погибли. На последнем этапе эксперимента (8 нед) выжило только 50\% крыс с критическим снижением массы тела по сравнению с контролем $(\mathrm{Me}=49,39$ г vs 16,0 г, $p<0,05)$.
2. Микроскопическое исследование ткани легкого. При исследовании микропрепаратов легочной ткани, окрашенных гематоксилином и эозином, наблюдали признаки патологического ремоделирования легочных сосудов (рис. 1, А-Г). Уже через 2 нед эксперимента и до его окончания отмечали признаки мускуляризации артериол с сохранением просвета сосудов и минимальной воспалительной инфильтрацией при отсутствии гиперплазии интимы и некроза эндотелиоцитов, что не сказывалось на общем состоянии животных (рис. 1, A). Через 1 мес периваскулярно увеличивалось количество лимфоцитов (рис. 1, Б). В артериолах наблюдалось утолщение интимы за счет минимально выраженной гиперплазии. Это часто сочеталось с атрофией мышечного слоя. Через 6 нед отмечались выраженные признаки недостаточности кровообращения, прогрессировали изменения интимы в виде выраженного фиброза, окклюзии просвета сосудов, значительной сосудистой воспалительной инфильтрации. В этой же группе наряду с констрикцией отмечалась дилатация отдельных артериол. На заключительном этапе (8 нед, гибель 50\% животных), в артериолах выявлялся концентрический фиброз интимы и некроз эндотелиоцитов (рис. 1, В). В некоторых образцах зафиксированы локусы плексиформной артериопатии (рис. 1, Г), что соответствует типичной картине ЛАГ. Для сравнительной оценки гистологических изменений в ткани легкого крыс с ЛАГ и контрольных животных использовали бальную шкалу оценки степени выраженности изменений: 0 - отсутствие изменений, 0,5 - минимально выраженные, 1 - слабо выраженные, 2 - умеренно выраженные и 4 - значительно выраженные изменения (табл. 1).

3. Оценка апоптоза эндотелиальных клеток легочных артерий. Через 2 нед эксперимента (TUNEL-окрашивание) выявлено незначительное количество эндотелиальных клеток (ЭК) легочных артерий с признаками апоптотической гибели (табл. 2). До 4-й нед наблюдали последовательное статистически значимое $(p<0,05)$ увеличение по отношению к группе контроля количества эндотелиальных клеток с признаками апоптотической гибели. С 4-й по 8 нед выявлено статистически значимое снижение апоптотического индекса (АИ) $(p<0,05)$, а к концу эксперимента (8 нед) существенных различий с группой контроля не наблюдалось.

4. Микроскопическая характеристика миокарда правого желудочка. На ранних стадиях отмечались преимущественно субсегментарные, реже, сегментарные контрактуры кардиомиоцитов, миокардиоцитолизис; на поздних сроках имела место так называемая волнистая 


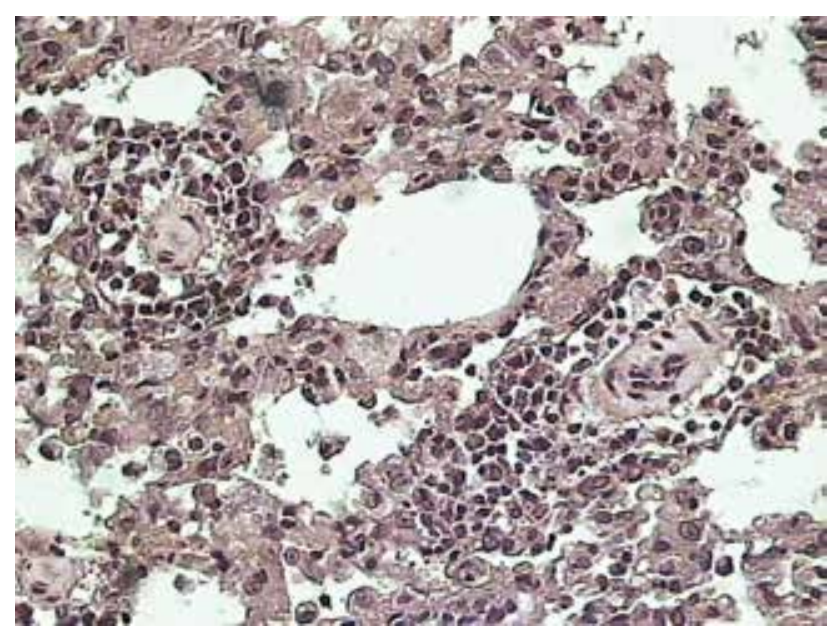

A

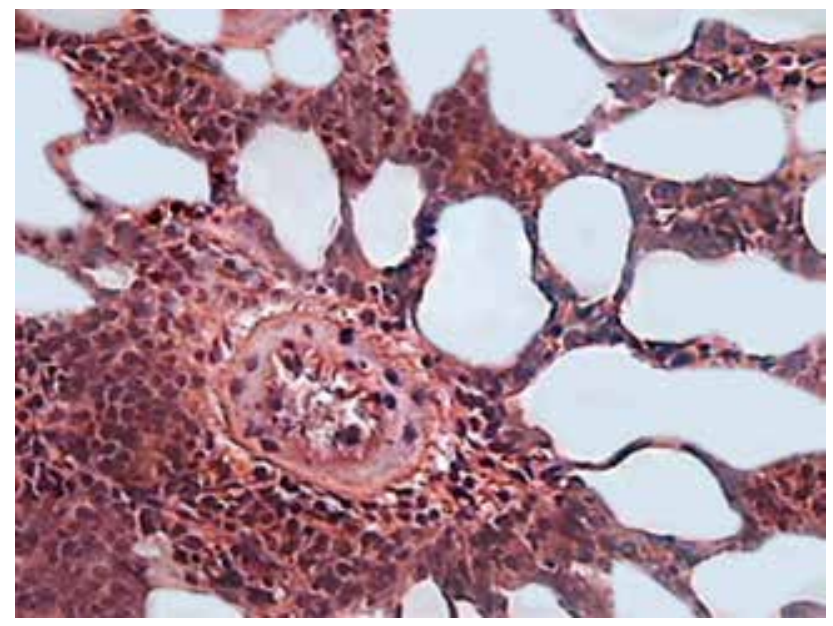

B

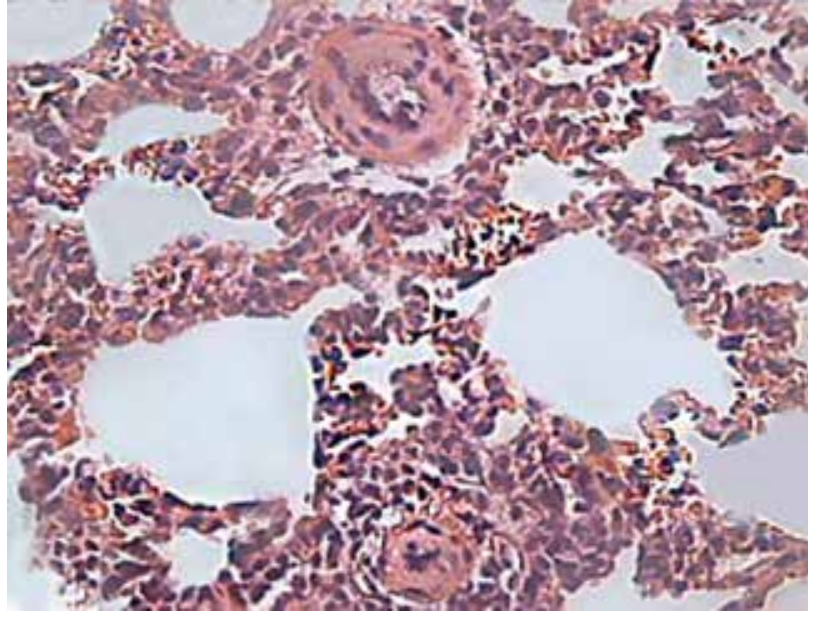

Б

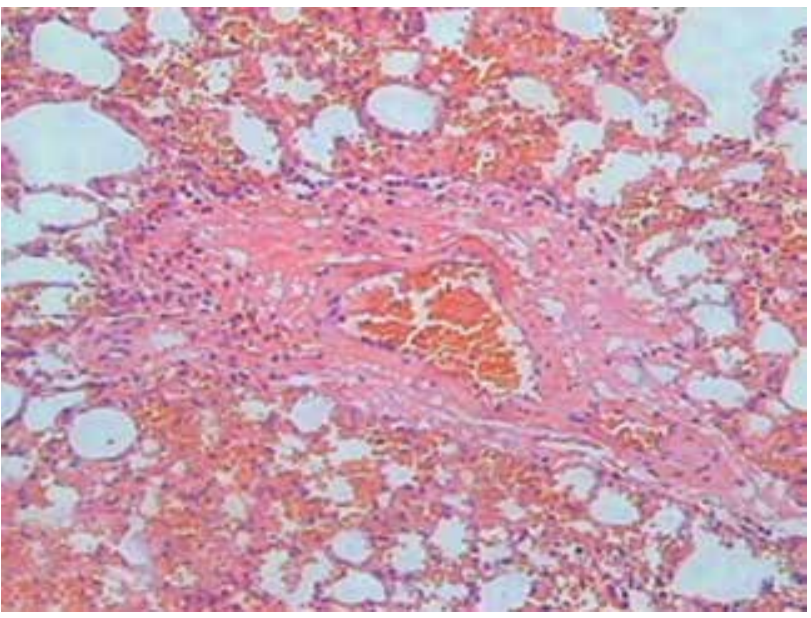

$\Gamma$

Рис. 1. Гистологические изменения легочной ткани крыс при развитии легочной артериальной гипертензии на разных стадиях. A - М2 группа, ув. ×400. Б - М4 группа, ув. ×400. В - М8 группа, ув. ×400. Г - М8 группа, ув. ×200. Окраска гематоксилином и эозином.

Таблица 1

\section{Оценка морфологических изменений в легочной ткани крыс при развитии монокроталиновой ЛАГ}

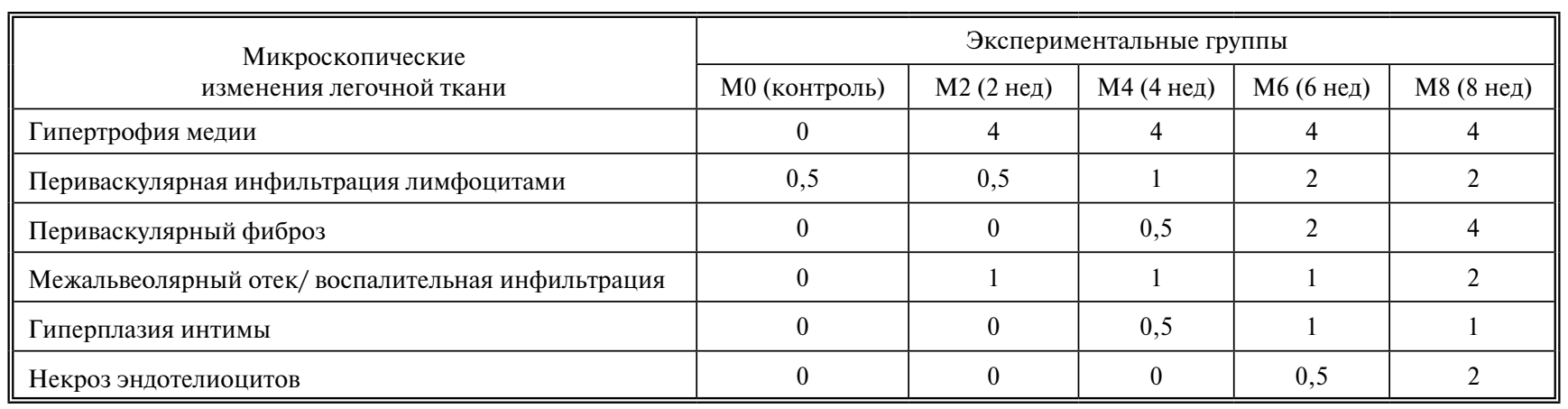


трансформация кардиомиоцитов (КМЦ), цитолиз (рис. 2, А), некроз отдельных КМЦ, очаги фиброза (рис. 2, Б).

5. Морфометрическая характеристика правых отделов сердиа и легочной артерии крыс. Как видно из таблиц 3 и 4, на ранних сроках эксперимента имела место тенденция к увеличению толщины стенки правого желудочка (ПЖ). Через 2 и 4 нед толщина стенки ПЖ была статистически значимо выше контроля $(p<0,05)$. Через 1 мес толщина ПЖ прогрессивно уменьшалась и не имела значимых отличий к 8-й нед наблюдения. В то же время существенно увеличивался поперечный размер полости правого желудочка (ППЖ) и диаметра ствола легочной артерии (ЛА) по сравнению с группой контроля $(p<0,05)$. Корреляци-

Таблича 2

Временная динамика апоптоза эндотелиальных клеток при разВитии ЛАГ, индуцированной монокроталином, Ме [25-й; 75-й процентиль]

\begin{tabular}{||l|c|}
\hline Группа (периоды наблюдения) & АИ, $\%$ \\
\hline М2 (2 нед) & $1,84^{*, \alpha, \beta, \alpha}[0 ; 3,25]$ \\
\hline M4 (4 нед) & $5,26^{*, \#, \beta, \alpha}[3,64 ; 7,28]$ \\
\hline M6 (6 нед) & $3,23^{*, \#, \alpha, \alpha}[2,38 ; 5,26]$ \\
\hline M8 (8 нед) & $1,39^{\#, \alpha, \beta}[0,00 ; 1,74]$ \\
\hline контроль & $0,01^{\#, \alpha, \beta, \alpha}[0,00 ; 0,01]$ \\
\hline
\end{tabular}

Примечание. АИ - апоптотический индекс, \%; статистически значимые различия $(p<0,05)$ по критерию Манна-Уитни: * - в сравнении с контрольной группой; \# - в сравнении с М2 группой; $\alpha-$ в сравнении с М4 группой; $\beta$ - в сравнении с М6 группой; $\alpha-$ в сравнении с М8 группой.

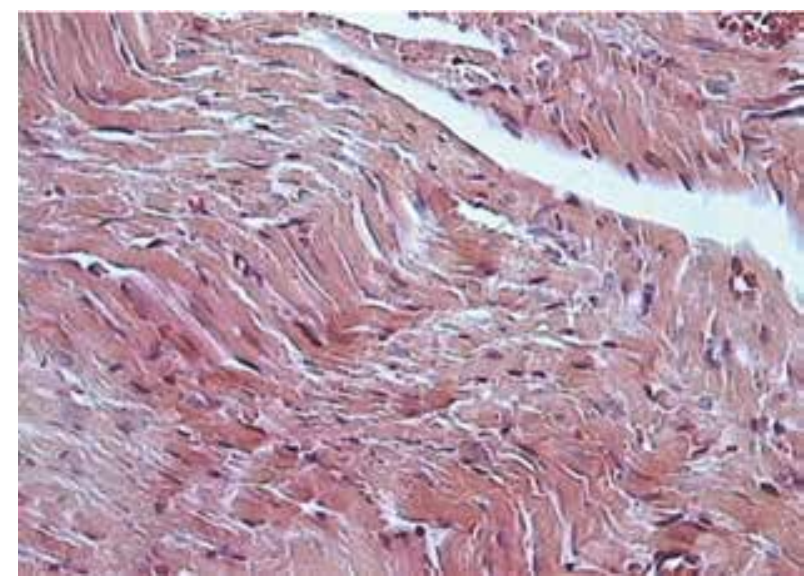

A онный анализ выявил умеренную обратную связь между толщиной стенки ПЖ и размером полости ПЖ и ЛА $(\mathrm{r}=-0.6, p=0.002)$.

Таким образом, по мере развития монокроталиновой ЛАГ уменьшается толщина стенки правого желудочка и увеличиваются размеры полости ПЖ и поперечные размеры ЛА.

Таблица 3

Временная динамика изменения толщины стенок камер сердца при ЛАГ, индуцированной монокроталином, Ме [25-й; 75-й процентиль]

\begin{tabular}{||c|c|c|c||}
\hline $\begin{array}{c}\text { Группа } \\
\text { животных }\end{array}$ & $\begin{array}{c}\text { ПЖ, мм } \\
{[25 \% ; 75 \%]}\end{array}$ & $\begin{array}{c}\text { МЖП+ЛЖ, мм } \\
{[25 \% ; 75 \%]}\end{array}$ & $\begin{array}{c}\text { ПЖ/(МЖП+ЛЖ), } \\
\text { мм [25\%;75\%] }\end{array}$ \\
\hline М2 (2 нед) & $\begin{array}{c}1,4^{*} \\
{[1,0 ; 1,6]}\end{array}$ & $\begin{array}{c}6,0 \\
{[4,5 ; 7,0]}\end{array}$ & $0,235[0,167 ; 0,3]$ \\
\hline М4 (4 нед) & $\begin{array}{c}1,7^{*} \\
{[1,2 ; 2,0]}\end{array}$ & $\begin{array}{c}6,0 \\
{[6,0 ; 6,0]}\end{array}$ & $0,283^{* *}[0,2 ; 0,3]$ \\
\hline М6 (6 нед) & $\begin{array}{c}1,2^{*} \\
{[1,1 ; 2,0]}\end{array}$ & $\begin{array}{c}6,0 \\
{[6,0 ; 7,0]}\end{array}$ & $\begin{array}{c}0,238 \\
{[0,117 ; 0,333]}\end{array}$ \\
\hline М8 (8 нед) & $\begin{array}{c}1,15 \\
(1,0 ; 1,5)\end{array}$ & $\begin{array}{c}5,2 \\
(5,0 ; 6,0)\end{array}$ & $0,208(0,2 ; 0,231)$ \\
\hline $\begin{array}{l}\text { М0 } \\
\text { (контроль) }\end{array}$ & $\begin{array}{c}0,9 \\
{[0,7 ; 1,0]}\end{array}$ & $5,0[5,0 ; 6,5]$ & $0,156[0,111 ; 0,2]$ \\
\hline \hline
\end{tabular}

Примечание. Наличие статистически значимых различий толщины стенки ПЖ по критерию Манна-Уитни $(p<0,05):$ * - в сравнении с контрольной группой; ** - наличие значимых различий ПЖ/(МЖП+ЛЖ) с контрольной группой; ПЖ - толщина стенки правого желудочка, мм; МЖП+ЛЖ - сумма толщины межжелудочковой перегородки и свободной стенки левого желудочка; ПЖ/(МЖП+ЛЖ) - отношение толщины стенки правого желудочка к сумме толщины межжелудочковой перегородки свободной стенки ЛЖ.

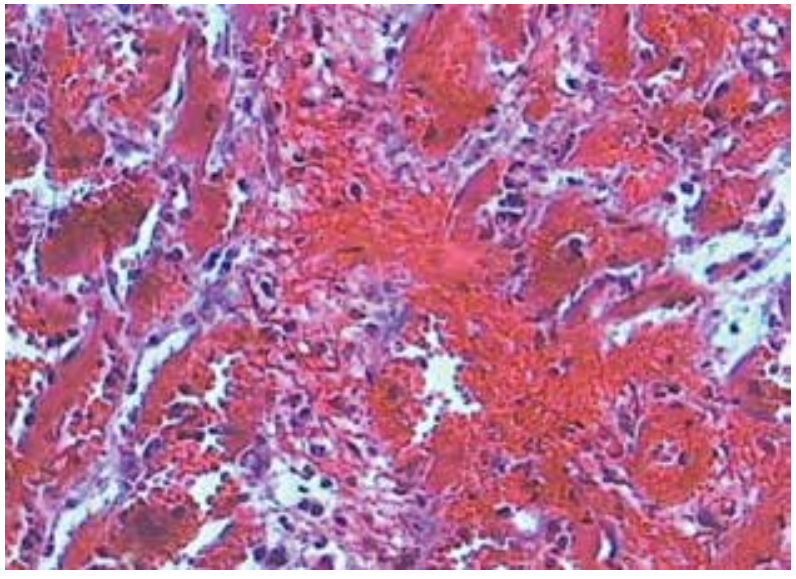

Б

Рис. 2. Временная динамика морфологических изменений в миокарде правого желудочка при развитии ЛАГ у крыс. А - группа М6 (6 нед), Б группа M8 (8 нед). Окраска гематоксилином и эозином ув. $\times 100$. 


\section{Обсуждение}

В проведенном исследовании подкожное введение монокроталина (60 мг/кг) через 8 нед завершалось структурным ремоделированием легочной ткани и миокарда правого желудочка.

До 4 нед эксперимента наблюдались начальные признаки ремоделирования легочной ткани и миокарда, что является обратимой стадией патогенетического процесса [1]. Это проявилось в виде гипертрофии медиального слоя легочных артерий без окклюзии сосудистого просвета на фоне незначительных периваскулярных лимфоцитарных инфильтратов, активацией апоптотической гибели эндотелиоцитов, сегментарных повреждений кардиомиоцитов с развитием гипертрофии правого желудочка. С 4-й нед и до конца эксперимента в участках легочной ткани с выраженной околососудистой воспалительной реакцией выявлялось преимущественно полное закрытие просвета легочных сосудов, обусловленное как гипертрофией медии, так и выраженным фиброзом интимы. Обнаружены также участки плексиформной артериопатии. В кардиомиоцитах правого желудочка выявлялись признаки некроза, фиброза, отмечалась дилатация правых отделов сердца. Подобная патоморфологическая картина свидетельствовала о необратимости процесса и дальнейшем его прогрессировании.

Как известно, монокроталин повреждает эндотелий легочных сосудов [4]. Вместе с тем, точные механизмы его токсического действия до сих пор остаются неясными. Данное вещество обладает быстрым и мощным краткосрочным повреждающим эффектом, так как быстро деградирует в водных средах, таких как плазма [5]. При этом подкожный способ введения способствует частичной аккумуляции монокроталина в эритроцитах и его пролонгированному повреждающему действию на легочную ткань [6].

К настоящему времени установлено, что монокроталиновый синдром регистрируется в широком интервале применяемых доз: от 2,4 до 300 мг/кг массы тела животных. Вместе с тем, имеются расхождения в эффектах в зависимости от дозы вводимого токсина. Более того, в разных исследованиях, при использовании одной и той же дозы (60 мг/кг) и одинаковом времени наблюдения, была показана различная степень гипертрофии правого желудочка. Например, M. Klein и соавт. [7] в экспериментальном исследовании определили индекс гипертрофии ПЖ (отношение массы правого желудочка к массе левого суммируемое с массой межжелудочковой перегородки) как $0,51 \pm 0,02$, a D. Benoist и его коллеги регистрировали этот же показа- тель в пределах 0,95 +/- 0,05 [8]. Еще в одном исследовании при использовании монокроталина (40 мг/кг) было отмечено восстановление функции правого желудочка через 8-12 нед [9]. Возможно, это говорит об обратимости изменений при введении монокроталина в дозе менее, чем использованная нами 60 мг/кг.

Имеются также расхождения в использовании токсической дозы препарата для успешного создания монокроталиновой модели, а также сроках наблюдения в динамике. Не менее важным является и тот факт, что не всеми исследователями выявлены морфологические признаки ЛАГ. Так, по данным литературы [10], при развитии ЛАГ путем введения монокроталина в дозе 40-60 мг/кг не было описано плексиформных повреждений, которые являются патогномоничным ее признаком. По-видимому, это объясняется очень быстрым, по условиям эксперимента, в течение 30 сут развитием правожелудочковой сердечной недостаточности с летальным исходом. Сочетанное воздействие механического фактора (пневмонэктомия) с последующим введением монокроталина также повторяет ключевые гистологические феномены ЛАГ в виде неоинтимального повреждения во многих дистальных отделах сосудистого русла, а также появление плексусов [11], но это уже иная модель, которая технически сложна для воспроизведения и требует значительных финансовых вложений.

Предполагается, что плексиформные изменения являются следствием апоптоза клеток легочных капилляров на ранних стадиях ЛАГ, в результате чего происходит пролиферация предшественников эндотелиальных клеток, устойчивых к апоптозу [12]. Обнаруженная нами активация апоптоза эндотелиоцитов на ранних сроках эксперимента (при 8-недельном наблюдении) мо-

Таблица 4

Временная динамика поперечных размеров полостей правых отделов сердца и легочной артерии при развитии ЛАГ, индуцированной монокроталином, Ме [25-й; 75-й процентиль]

\begin{tabular}{||c|c|c|c||}
\hline $\begin{array}{c}\text { Группа } \\
\text { животных }\end{array}$ & $\begin{array}{c}\text { ППЖ, мм } \\
{[25 \% ; 75 \%]}\end{array}$ & $\begin{array}{c}\text { ППП, мм } \\
{[25 \% ; 75 \%]}\end{array}$ & $\begin{array}{c}\text { Ствол ЛА, мм } \\
{[25 \% ; 75 \%]}\end{array}$ \\
\hline M8 & $\begin{array}{c}3,76^{*} \\
{[3,7 ; 3,8]}\end{array}$ & $\begin{array}{c}5,49^{*} \\
{[5,4 ; 5,6]}\end{array}$ & $\begin{array}{c}3,37^{*} \\
{[3,2 ; 3,8]}\end{array}$ \\
\hline Контроль M0 & 3,2 & 3,07 & 2,9 \\
& {$[3,2 ; 3,3]$} & {$[3,0 ; 3,1]$} & {$[2,8 ; 3,1]$} \\
\hline
\end{tabular}

Примечание. * - наличие статистически значимых различий величин по критерию Манна-Уитни в сравнении с контрольной группой $(\mathrm{p}<0,05)$; ППЖ - поперечный размер полости правого желудочка; ППП - поперечный размер полости правого предсердия; ствол ЛА - диаметр ствола легочной артерии. 
жет носить компенсаторный характер, направленный на уменьшение степени гиперплазии интимы. Однако в динамике эксперимента происходит образование плексусов на последнем этапе исследования, что подтверждает появление апоптозрезистентных эндотелиальных клеток и доказывает идентичность данной модели естественному течению ЛАГ.

В нашем исследовании не ставилась задача определения уровня давления в легочной артерии. Нами проведена оценка морфологических изменений в легочной ткани и миокарде правого желудочка, которые сопровождают развитие ЛАГ. Увеличив период наблюдения до 8 нед и использовав наиболее распространенную (по данным литературы) дозу токсина (60 мг/кг), нами были выявлены основные группы патогистологических признаков ЛАГ, а именно: 1) плексиформные повреждения, которые наиболее ярко иллюстрируют сосудистые изменения; 2) дилатационные поражения легочных артериол; 3) классический артериит с трансмуральной воспалительной реакцией и признаками фибриноидного некроза [1].

Таким образом, подкожное введение монокроталина крысам в дозе 60 мг/кг способствует развитию в течение 8 нед типичных для ЛАГ патогномоничных изменений в легочной ткани и миокарде правого желудочка, которые носят необратимый характер, начиная с 4-й нед наблюдения.

\section{Участие авторов:}

Концепция и дизайн исследования - Адзерихо И.Э. Сбор и обработка материала - Владимирская Т.Э., Яцевич О.Н., Михневич Д.Л.

Статистическая обработка - Яцевич О.Н., Михневич Д.Л.

Написание текста - Яцевич О.Н.

Редактирование - Адзерихо И.Э., Владимирская Т.Э.

\section{Литература}

\section{(п.п. 1; 3-12 см. References)}

2. Денисов, С.Д., Морозкина Т.С. Требования к научному эксперименту с использованием животных. Здравоохранение. 2001; 4 : $40-2$.
3. Ерохина И. Л., Оковитый С. В., Казаченко А. А., Куликов А. Н., Емельянова О. И., Быстрова О. А. Резкое увеличение плотности тучных клеток в легких и перикарде при монокроталининдуцированной легочной артериальной гипертензии у крыс. Цитология. 2011; 53(1): 39-43.

\section{References}

1. Pulmonary hypertension/ed. by Marc Humbert, Joseph P. Lynch III. Informa Healthcare, 2009. (Lung Biology in Health and Disease, Volume 236) - ISBN 9781420094756.

2. Denisov S.D., Morozkina T.S. Trebovanija k nauchnomu jeksperimentu ispol'zovaniem zhivotnyh. Zdravookhranenie. 2001; 4: 40-2. (In Russian).

3. Erokhina I.L., Okovityy S.V., Kazachenko A.A., Kulikov A.N., Emelyanova O.I., Bystrova O.A. Sharp increase in density of pulmonary and pericardial mast cells in monocrotaline-induced pulmonaryhypertension in rats. Tsitologiya. 2011; 53(1): 39-43. (In Russian)

4. Kay JM., Smith P., Heath D. Electronic microscopy of Crotalaria pulmonary hypertension. Thorax. 1969; 24(5): 511-26.

5. Bruner LH., Carpenter LJ., Hamlow P., Roth RA. Effect of a mixed function oxidase inducer and inhibitor on monocrotaline pyrrole pneumotoxicity. Toxicol Appl Pharmacol. 1986; 85(3): 416-27.

6. Pan LC., Lame MW., Morin D., Wilson DW., Segall HJ. Red blood cell augment transport of reactive metabolites of monocrotaline from liver to lung in isolated and tandem liver and lung preparation. Toxicol Appl Pharmacol. 1999; 110(2): 336-46.

7. Klein M., Schermuly RT., Ellinghaus P., Milting H., Riedl B., Nikolova S. et al. Tyrosine and Serine/Threonine Kinase Inhibition by Sorafenib Prevents Progression of Experimental Pulmonary Hypertension and Myocardial Remodeling. Circulation. 2008; 118(20): 2081-90.

8. Benoist D., Stones R., Drinkhill M., Bernus O., White E. Arrhythmogenic substrate in hearts of rats with monocrotaline-induced pulmonary hypertension and right ventricular hypertrophy. Heart and Circulatory Physiology. 2011; 300(6): 2230-7.

9. Wennerstrom A., Pietinalho A., Lasota J., Salli K., Surakka I., Seppanen M. et al. Reversibility of the monocrotaline pulmonary hypertension rat model. European Respiratory Journal. 2013; 42(2): 550-3.

10. Gomez-Arroyo JG., Farkas L., Alhussaini AA., Farkas D., Kraskauskas D., Voelkel NF. et al. The monocrotaline model of pulmonary hypertension in perspective. Lung Cellular and Molecular Physiology. 2011; 302(4): 363-9.

11. White RJ., Meoli DF., Swarthout RF., Kallop DY., Galaria II., Harvey Jl. et al. Pexiform-like lesions and increased tissue factor expression in a rat model of severe pulmonary arterial hypertension. $\mathrm{Am} J$ Physiol Lung Cell Mol Physiol. 2007; 293(3): 583-90.

12. Tuder RM., Abman SH., Braun T, et al. Development and pathology of pulmonary hypertension. J Am Coll Cardiol. 2009; 54: Suppl. 1, 3-9.

Сведения об авторах:

Адзерихо Игорь Эдуардович, доктор мед. наук, проф. каф. клинической фармакологии и фармакотерапии БелМАПО, e-mail: adzerikhoigor@mail.ru;

Владимирская Татьяна Эрнстовна, канд. биол. наук, вед. науч. сотр., руководитель отдела общей патологии НИЛ БелМАПО, e-mail: tan_2304@inbox.ru;

Михневич Дарья Леонидовна, мл. науч. сотр. отдела общей патологии НИЛ БелМАПО, e-mail: dashundik@mail.ru;

Яцевич Ольга Николаевна, мл. науч. сотр. отдела общей патологии НИЛ БелМАПО, e-mail: o-n-y@yandex.ru 